\title{
Dampak Media Sosial terhadap Usaha Kecil dan Menengah (UKM) SENTRA Industri Keramik Plered, Kabupaten Purwakarta
}

\author{
(Suatu Tinjauan TeOritis) \\ ${ }^{1}$ Danang Sanggabuwana, ${ }^{2}$ Susi Andrini \\ email: 'Sangga_buwana@yahoo.com, ${ }^{2}$ Ussie69@gmail.com
}

\begin{abstract}
The development of social media makes it recommended that social media become the most important part in developing and advancing its business especially in the field of promotion, marketing and marketing as a whole. The existence of today's social media applications has become the most efficient and effective tool for ceramic SMEs in Ceramic Plered Industrial Center, Purwakarta District, and today most of the SMEs have followed the digital era by using social media platform for marketing communications, advertisement, product publicity ceramics and services they provide. They create fan pages for followers to make communication fast, even in different cities or countries SME ceramic actors can warmly welcome advice and opinions that help in improving their business. Based on the review that there is a positive impact although there is also a negative impact of social media applications on the development of business SMEs ceramic entrepreneurs but not undo the intention to advance its business, and motivated to use this platform.
\end{abstract}

Keywords: media, social media

\section{Pendahuluan}

Pada Era milinium ini, peran media sosial sangat membantu UKM untuk menyebarluaskan bisnis mereka dalam upaya promosi, pengenalan produk sampai pada penjualannya. Kegiatan surfing internet sudah menjadi bagian penting dari kehidupan sehari-hari, mulai dari belanja lewat surat elektronik sampai hal-hal remeh temeh bahkan ke soal pendidikan maupun dalam berbisnis dengan dunia luar. Internet menjadi perkembangan teknologi yang sangat pesat dan ketika kita berbicara tentang jaringan media sosial, sangat bermanfaat bagi setiap jenis bisnis dan pengusaha sehingga menjadi sangat umum dan tersebar luas dalam beberapa tahun terakhir ini . Di era digital ini, sebagian besar bisnis menggunakan media sosial untuk meningkatkan hubungan mereka dengan konsumen. Media sosial memberikan cara baru untuk berbisnis dan berkomunikasi cara baru dalam tehnik komunikasi antar personal dengan pelanggan; Ini benar-benar mengubah cara bisnis konvensional yang memakai cara lama itu secara langsung untuk bertemu pada realitynya. Namun dengan sebuah aplikasi online yang memungkinkan penggunanya berinteraksi satu dengan lainnya lewat media sosial bisa dengan cepat berinteraksi meskipun secara fisik tidak bertemu, dalam hal ini termasuk menciptakan dan berbagi konten bisnis mereka. Dibandingkan media tradisional yang hanya mengantarkan konten sosial, mempromosikan partisipasi pengguna aktif, media sosial jauh lebih menguntungkan dibanding cara-cara konvensional sebelumnya. Ada berbagai macam media sosial, mulai dari jejaring sosial (facebook, Linked-In, Whatsapp, Line, Instagram) jejaring sosial pribadi (yammer, social cast, jive) situs berbagi konten (YouTube, flicker) ke blog wiki 
(Wikipedia) (blogger, word press) dan blog mikro (twitter).

Melalui jejaring media sosial ini adalah gerbang bagi perusahaan untuk mendapatkan keuntungan dan tumbuh di industri keramik ini. Perusahaan semakin tertarik untuk menggunakan media sosial baik untuk tujuan bisnis khususnya yang merupakan bagian dari komunikasi, pemasaran maupun perekrutan mereka. Jejaring sosial telah menjadi praktik sehari-hari dalam kehidupan pengguna di masyarakat kita juga para pengusaha UKM. Ini tidak hanya menawarkan kesempatan luas namun juga menghadirkan tantangan yang signifikan bagi pengusaha. Pengusaha bisnis kecil menggunakan aplikasi media sosial untuk menyebarkan bisnis mereka dengan menggunakan berbagai ikatan lemah dan pentingnya ikatan lemah dalam jaringan pemilik bisnis kecil diidentifikasi oleh Granovetter [1973] dan Burt [2004]. Tujuan dari ikatan yang lemah adalah untuk mengumpulkan informasi mengenai bisnis oleh pemilik UKM. Alasan penggunaan aplikasi media sosial adalah menjaga koneksi dengan weakties. Hal ini akan membantu membangun reputasi bisnis yang baik dan membantu untuk berkomunikasi antara pelanggan (saat ini dan potensial) dalam hal umpan balik, pengembangan produk dan definisi serta layanan dan dukungan pelanggan. Media sosial menjadi salah satu cara termudah untuk meningkatkan produktivitas. Namun, Shabbir [2015] menguraikan bahwa inovasi pasar adalah alat yang komprehensif untuk memenuhi kebutuhan dan keinginan target pelanggan mereka.

\section{Kerangka Koseptual}

\section{Definisi Media Sosial}

Sejak dimulainya jejaring sosial pada tahun 1997, dengan diluncurkannya fitur blogging dan posting melalui web 2.0 dinamakan six degress.com. Tujuan dasar dari situs ini adalah untuk memfasilitasi orang-orang dalam hal konektivitas sosial melalui LinkedIn, My Space Orkut, Google talk, Skype, Hangout dan lain-lain. Cheung dan Lee [ 2010] menyatakan bahwa," "the driving forces behind online social networks are connections and community, and the usage is largely depended on subjective norm and social identity". "the driving forces behind online social networks are connections and community, and the usage is largely depended on subjective norm and social identity". Mangold dan Faulds [2009] mendefinisikan bahwa "Social media is a hybrid element of promotion mix because in traditional sense it enables companies to talk their customers while in a non-traditional sense it enables customers to talk directly to one another. Dengan bantuan media sosial orang-orang menikmati hidup mereka dengan lancar dan tetap terhubung dengan relasi mereka, dan juga memberikan banyak informasi penting untuk berbagai tujuan [2004], usso, J. Watkins, L. Kelly, dan S. Chan (2008) - Media sosial adalah instrumen yang memfasilitasi komunikasi, jaringan, dan/atau kolaborasi secara daring.

Sedangkan fungsi media sosial dapat kita ketahui melalui sebuah kerangka kerja honeycomb. Pada tahun 2011, Jan H. Kietzmann, Kritopher Hermkens, Ian P. McCarthy dan Bruno S. Silvestre menggambarkan hubungan kerangka kerja honeycomb sebagai penyajian sebuah kerangka kerja yang mendefinisikan media sosial dengan menggunakan tujuh kotak bangunan fungsi yaitu identity, 
cenversations, sharing, presence, relationships, reputation, dan groups.

1. Identity menggambarkan pengaturan identitas para pengguna dalam sebuah media sosial menyangkut nama, usia, jenis kelamin, profesi, lokasi serta foto.

2. Conversations menggambarkan pengaturan para pengguna berkomunikasi dengan pengguna lainnya dalam media sosial.

3. Sharing menggambarkan pertukaran, pembagian, serta penerimaan konten berupa teks, gambar, atau video yang dilakukan oleh para pengguna.

4. Presence menggambarkan apakah para pengguna dapat mengakses pengguna lainnya.

5. Relationship menggambarkan para pengguna terhubung atau terkait dengan pengguna lainnya.

6. Reputation menggambarkan para pengguna dapat mengidentifikasi orang lain serta dirinya sendiri.

7. Groups menggambarkan para pengguna dapat membentuk komunitas dan sub-komunitas yang memiliki latar belakang, minat, atau demografi.

https://pakarkomunikasi.com/pe

ngertian-media-sosial-menurut-para-ahli

\section{Media Sosial UKM}

Hampir semua bisnis mempertimbangkan penggunaan media sosial untuk memasarkan / merek beberapa produk. UKM menggunakan aplikasi media sosial sebagai alat pemasaran untuk merek dan pemasaran produk mereka. Pendekatan praktis telah diikuti oleh Karkkainen [2010]

investigating general companies to actually see how much of the social media application has actually penetrated. the nontechnology and traditional organizations. Based on survey results he finds application of social media by businesses is inclined more towards communication to the customer in the traditional sense like branding, public relations and lead generation rather than communication with the customer, understanding the customer and internal communications. Strategi UKM adalah mengadopsi micro blogging untuk berhubungan langsung dengan individu yang memiliki minat dalam bisnis Shabbir [2015]. Gunther dkk. [2009] mengatakan bahwa social media helps small business entrepreneurs to build their small community over that media for smooth interaction with their partners. Motivasi untuk mengadopsi blogging mikro oleh bisnis kecil pengusaha telah membuat koneksi lebih tepat mengarahkan hubungan dengan orang-orang yang memiliki kepentingan bisnis yang sama atau umum dan karenanya bisnis khususnya UKM dan menengah mencoba untuk menerapkan micro blogging sebagaimana terbukti dari penelitian Gunther dkk., [2015], Meyer dan Dibbern [2009], Fischer dan Reuber [2010], Riemer dan Richter [2010] yang membukti bahwa there is a new trend of using face book by small business users due to cost saving as well time saving in order to promote their products as well as use face book for connecting themselves with weak ties and career advancement. Fischer dan Reuber mengatakan bahwa "in the relatively few scholarly studies that consider how such social media may benefit firms, the majority has focused on social media as marketing tools and also suggest that entrepreneurs who have used twitter that "entrepreneur learned that he could connect to his customers even more effectively than he had been doing". 
CEO Young On Top Billy Boen, mengungkapkan bahwa ada perubahan perilaku konsumen saat ini dari era konvensional kepada era digital, dimana 84 persen (84\%) konsumen membeli barang lewat media sosial baik itu Facebook, Twitter, Instagram, Youtube, dan Line. Oleh karenanya, kini, UKM menggunakan beragam aplikasi di media sosial untuk meningkatkan pertumbuhan bisnis dan publisitas, karena sejumlah besar bidang terkait bergabung dengan laman mereka, itulah sebabnya mereka mendapatkan lebih banyak dan berbagi pengetahuan satu sama lain untuk menghasilkan perluasan bisnis mereka. Sebagai contoh pengusaha UKM keramik menggunakan website untuk memasarkan produknya seperti dengan menggunakan blog http://alegostudio.com/keramik-madein-plered-purwakarta/ dan http://www.keramikmulyaplered.com/ untuk memasarkan produk keramiknya bahkan sudah banyak mengekspor karya-karya ke Eropa sebagai dampak penggunaan media sosial.

Dengan berlalunya waktu, tidak diragukan lagi bahwa teknologi menjadi lebih cepat dan tepat serta membuat kehidupan orang lebih mudah, di sisi lain oportunis memanfaatkan fasilitas ini dan memberi ide baru pada faset. Pengusaha akan menggunakan media sosial untuk terhubung dengan konsumen atau pelanggan atau mencoba untuk meningkatkan kontak dengan ikatan kuat yang ada. UKM keramik di Sentra Industri keramik menggunakan media sosial lebih karena ini adalah tentang bersosialisasi dan berbagi pendapat. Pendapat ini bisa dinyatakan sebagai masukan tertulis dalam bentuk posting blog atau komentar, presentasi video dan suara di situs media sosial. Pendapat ini langsung dan tanpa filter Shabbir [2014]. Keterbukaan pendapat ini merupakan salah satu perubahan utama media sosial yang mengenalkan hubungan antara bisnis dan pelanggan.

Pentingnya Usaha Mikro Kecil Menengah (UMKM) memanfaatkan keberadaan media sosial (medsos) dalam upaya untuk meningkatkan kinerja penjualan produknya. Pelaku UKM dengan memanfaatkan media sosial maka hambatan jarak, ruang dan waktu, serta harga barang, bisa tereliminir. UKM tidak perlu dan tidak membutuhkan ruang yang besar untuk memamerkan/ memajang produknya. Disamping itu Jarak juga tidak menjadi hambatan untuk mengirim barang, karena sudah banyak perusahaan jasa kurir untuk mengantar barang dengan harga yang murah dan cepat sampai ke konsumen. Jangkauan pemasaran pun bisa mendunia. Tenaga kerja juga bisa dimanfaatkan dengan efektif dan efisien. Oleh karena itu, para pelaku UKM khususnya di Indonesia sudah mulai melangkah mempromosikan dan menjual produknya melalui media sosial agar tidak tergilas zaman.

Pengusaha menggunakan media sosial sebagai alat pemasaran karena melalui alat ini mereka bisa membangun jaringan pendukung yang sangat cepat yang penting bagi pertumbuhan bisnis. Karena pendukung ini tetap membawa pelanggan / bisnis bagi pengusaha UKM dengan cara merujuknya kepada orang lain. Media sosial membantu menciptakan hubungan jangka panjang antara bisnis dan pelanggan. Namun ada beberapa isu yang terkait dengan media sosial pada awalnya adalah kekhawatiran bisnis tentang implementasi media sosial adalah kurangnya konsensus tentang bagaimana dua menerapkan berbagai aktivitas karena platform dan teknologinya begitu dinamis dan belum ada panduan yang jelas untuk bisnis bagaimana cara memanfaatkannya. Sebagian besar bisnis menggunakan pendekatan eksperimental mereka 
sendiri untuk mencapai hasil yang lebih baik dan ini membuat tugas menjadi lebih menantang. Yang kedua adalah menerapkan Sosial Media sebagai tugas menetapkan tujuan yang jelas dan sejumlah besar bisnis bergabung dengan media sosial setiap tahunnya, namun mereka yang mempertahankannya kehadiran online secara efektif relatif rendah, hal ini karena banyak dari bisnis ini meluncurkan kampanye media sosial tanpa tujuan strategis yang jelas. Gillin [2009] menjelaskan bahwa kebanyakan bisnis ingin bereksperimen dengan teknologi atau mungkin mereka tertarik dengan biaya masuk yang rendah dan dia menyarankan untuk bereksperimen lebih baik daripada tidak bertindak, tapi lebih baik lagi jika memiliki sebuah rencana. Tuten [20] menyarankan jika sebuah bisnis mendapatkan keuntungan dari pemasaran media sosial, langkah pertama dalam prosesnya adalah menetapkan tujuan kampanye, karena menetapkan tujuan merupakan langkah penting dalam proses perencanaan komunikasi dan pemasaran. Menurutnya, setiap kampanye pemasaran tanpa tujuan tidak dapat diukur dan dievaluasi, kecuali jika kita dapat mengukur kinerja, hal itu dapat dianggap sebagai pemborosan usaha.

Sebenarnya ada beberapa cara sederhana bisnis untuk mendapatkan manfaat dari perencanaan pemasaran dalam menggunakan media sosial yang efektif, antara lain adalah, 1. media sosial dapat mengurangi seluruh biaya pemasaran. Penggunaan twitter, Facebook bahkan Grup Whatsapp jauh lebih murah dibanding harus membuat brosur sebagai sarana promosi dan pemasaran. 2. Media Sosial dapat mempengaruhi hasil pencarian di mesin pencari. Artinya pengusaha UKM berharap media sosial dapat mempengaruhi posisi website bisnis di mesin pencari, caranya adalah dengan membuat konten optimal yang menarik, sehingga website lain akan tertarik dengan isi kontennya, lalu membuat link ke website - tentu akan meningkatkan traffic ke website. Media sosial menjadi alat yang tepat untuk mencari pengunjung yang sesuai, dan kemudian mereka akan terus mengunjungi, bahkan menyebarkan websitenya secara gratis. 3. Media Sosial dapat menjadi customer service yang baik, dalam artian pelanggan yang menggunakan media sosial seperti Facebook atau Twitter dapat dengan mudah berkomunikasi, dan memungkinkan pengusaha UKM dapat merespons komentar pelanggan, serta pelanggan lain juga dapat melihatnya. 4. Dengan Media Sosial pengusaha UKM dapat mendesain kepribadian online sesuai dengan karakter yang dimilikinya sesuka hati. Media sosial adalah cara yang tepat menunjukkan kepribadian dari bisnis UKM, yang bisa menampilkan informasi, karyawan, ruang kerja, dan masih banyak lagi. Membuat brand image pada perusahaan dan merk yang mudah diingat sehingga pelanggan akan mudah terhubung dan menjaga loyalitas. 5. Media Sosial memungkinkan pengusaha UKM terhubung dengan bisnis lain. Jika memang media sosial dapat menghubungkan pengusaha dengan konsumen, berarti platform ini juga memungkinkan untuk terhubung dengan pengusaha atau bisnis usaha kecil menengah lainnya. Dan sangat memungkinkan juga mendapatkan partner untuk distributor baru lainnya, dengan media sosial dapat melakukan percakapan yang nyata dengan manusia sesungguhnya yang dapat di akses secara sosial dan geografis. 6. Pelanggan bisa memvalidasi bisnis untuk pengusaha UKM keramik di Media Sosial dengan terhubungnya 
pelanggan secara langsung. Berarti ada kemungkinan mereka mendapatkan layanan pelanggan yang terbaik. Hal ini akan terjadi di forum publik yang dapat dilihat oleh semua orang. Jadi ketika pelanggan memberikan pujian pada pelayanan dari pembuat web (pengusaha UKM) bisa memvalidasi ke teman-teman mereka, maka akan sangat mungkin teman- teman mereka menjadi pelanggan potensial juga. 7. Dengan Media Sosial pengusaha UKM keramik dapat memberi nilai berharga, Jika pengusaha UKM dapat memenuhi keinginan pelanggan, itu berarti ia telah memberi nilai berharga yang akan diapresiasi oleh pelanggan. 8. Media Sosial memungkinkan pengusaha UKM mendapatkan keunggulan kompetitif. Jika digunakan dengan benar, media sosial dapat meningkatkan tingkat pencarian pada bisnis UKM, dengan memberi layanan pelanggan terbaik, mendesain kepribadian online yang efektif, terhubung dengan mitra bisnis baru, membangun koneksi, dan memvalidasi keahlian dengan memberi nilai berharga pada konsumen. Jadi apakah artinya itu ? itu berarti pengusaha UKM mendapatkan keunggulan kompetitif untuk bersaing, dan itu semua didapatkan dari media sosial (medsos)

Namun begitu disamping

beberapa keuntungan yang memberikan efek positif dan efek negatifnya dalam melalukan media sosial. Menurut Alo Lileweri (2015 : 326) yang megatakan bahwa, Media Sosial memungkinkan individu untuk mengenal dan menjalin hubungan hubungan teman baru secara kumulatif dan terhubung ke sekelompok besar orang-orang yang mempunyai katagori sosial/antropologis demografis. Media sosial telah memungkinkan orangorang dari berbagai bangsa dan negara untuk mengembangkan hubungan dan komunikasi antarpersonal yang efektif orang dapat berinteraksi dan banyak tentang orang lain termasuk belajar tentang budaya mereka. Sedangkan efek negatifnya sebagian mereka yang terlibat dalam komunikasi melalui medsos sering mengeluh karena menghabiskan sebagian besar waktu kontak satu sama lainnya, ini terjadi karena masing-masing pihak mempunyai motivasi yang sangat tinggi untuk mengetahui perkembangan keseharian partnernya. Ancaman terbesar media sosial antara lain dapat menimbulkan kepalsuan hubungan mengingat orang tidak tahu persis kredibilitas seseorang berdasarkan profil yang ada di situs media. Kerap kali penipuan terjadi karena orang memakai profil palsu. Atau memposting informasi yang salah tentang diri mereka sendiri, memanipulasi fakta dan membesarbesarkan kebenaran. Hubungan berbasis media sosial seperti ini memiliki resiko tinggi karena orang lain dapat mengambil keuntungan lain yang tidak semestinya. Sering pula hubungan yang dikembangkan melalui media sosial cenderung santai dan menyebabkan gejolak emosional yang mendorong orang mempercayai seseorang secara membabi buta. Seiring dengan itu berbagai pengamatan menunjukkan bahwa hubungan yang bersifat konfrontatif lebih mudah 'dinikmati' d media sosial dibandingkan dengan ketika berkomunikasi tatap muka (Rahul Pandita. 2011)

Dalam hal ini antara pengusaha UKM keramik dan konsumen atau pelanggan dimana pengusaha memanfaatkan sebaik-baiknya media sosial tetap harus berhati-hati akan efek negatif yang telah dipaparkan diatas. Komunikasi di dunia maya memang terkadang tidak sama dengan apa yang ada dalam realitanya (kenyataan) 
sehingga dapat mengecoh diantara kita. Apalagi jika sudah terjadi transaksi diantara keduanya. Salah-salah barang sudah dikirim tapi tak dibayar-bayar. Atau sebaliknya sudah membayar lunas namun produk tidak sampai. Di sinilah perlu kehati-hatian dan kewaspadaan dalam menjalankan bisnis di media sosial, pada ruang dunia tanpa batas ini. Sehingga dengan adanya ini perlu dibuat rule dan sanksi-sanki bilamana promosi, iklan, pemasaran, ataupun komunikasi yang terjadi di media sosial menghasilkan hal-hal negatif sehingga jauh dari kata efektif dan terpercaya.

\section{Dampak Positif dan Negatif Media Sosial}

Media Sosial dirancang untuk dapat menjangkau banyak orang, dari berbagai kalangan usia juga peran sosial. Berbagai informasi tersebar luas dan dapat dengan mudah kita dapatkan dari sosial media. Sehingga pengguna sosial media seringkali mendapatkan lebih banyak informasi dalam waktu yang lebih cepat dari pada orang yang tidak menggunakan sosial media. Keberadaan media sosial memang dirasakan banyak manfaatnya. Namun, penggunaan media sosial yang tidak baik, misalnya menciptakan atau membagikan isi konten sosial media yang berisi penipuan, hoax dan sebagainya akan menyebabkan timbulnya opini publik yang merugikan banyak pihak. Untuk lebih jelasnya, berikut akan dipaparkan efek media sosial pada komunikasi.

\section{Dampak Positif}

1. Sumber infomasi, lebih mudah dan cepat didapatkan serta lebih transparan. Informasi yang dapat ditemukan di sosial media sangat beragam, mulai dari bahan pekerjaan, pendidikan, masakan, hingga bahan ringan seperti game atau komik.

2. Media komunikasi, dengan jangkauan luas, kemudahan penggunaan, dan biaya yang relatif murah. Contohnya dengan whatsapp saya bisa melakukan panggilan video pada teman saya yang berada di negara Jepang dengan biaya yang sangat murah.

3. Memperluas pergaulan, terhubung dengan teman lama ataupun membuat pertemanan baru dengan mudah)

4. Bertukar informasi ataupun data, seperti foto/ video dengan mudah dan cepat.

5. Ajang promosi dengan jangkauan yang lebih luas, mudah, murah namun terfokus. Seperti memperkenalkan produk kepada khalayak ramai lewat instagram, menggunakan facebook advertising, dll.

6. Hiburan, misalnya dengan mengunjungi website berisi humor, e-novel, e-komik atau sekedar membaca portal bacaan ringan.

7. Membangun opini atau mengemukakan pendapat secara luas. Suatu opini yang dibagikan lewat sosial media dapat menjadi viral dan menjangkau hingga lintas negara bahkan seluruh dunia.

8. Mempelajari sesuatu, contohnya dengan menonton video cara membuat kue tart, membuat baju, atau merias.

9. Kesempatan menjadi orang yang berbeda. Misalnya orang yang cenderung pemalu akan bisa lebih aktif mengemukakan pendapatnya lewat sosial media. 
10. Membangun rasa percaya diri seseorang dalam bersosialisasi.

\section{Dampak Negatif}

1. Terjadi kesenjangan informasi. Baik antara pengguna sosial media yang bisa mendapatkan berbagai informasi dengan mudah dan transparan dengan orang yang tidak menggunakan sosial media, atau antara pengguna sosial media itu sendiri, misalnya antara yang bergabung dalam suaru grup dengan yang tidak bergabung

2. Kecanduan media sosial, maksudnya seseorang menjadi sangat terikat dengan media sosial. Menghabiskan sebagian besar waktu hariannya untuk berinteraksi dalam sosial media, hingga seringkali mengabaikan orang disekelilingnya bahkan tugas-tugas yang seharusnya dikerjakannya.

3. Berkurangnya intensitas dalam berinteraksi langsung dengan sesama.

4. Menimbulkan kecemburuan sosial. Misalnya dengan memposting berbagai barang bermerek atau semacamnya di sosial media

5. Menciptakan identitas baru yang sama sekali tidak sesuai dengan identitas diri.

6. Pencurian identitas, misalnya dengan membuat akun facebook seorang artis dan membuatnya seolah-olah milik artis tersebut

7. Pencurian/ penyalahgunaan data seperti foto, dokumen, dkk. a menci

8. Men ptakan konten berisi hoax.

9. Konsumtif, misalnya menjadi tertarik dengan berbagai iklan dan melakukan pembelian menggunakan kartu kredit tanpa berpikir panjang.
10. Mempermudah penyebaran virus. Misalnya dengan membuat konten berisi link menuju laman tertentu yang disisipi virus.

Untuk mencegah dampak media sosial yang negatif, pengusaha UKM keramik harus memahami dan melaksanakan etika komunikasi di internet. Pastikan ketika kita menciptakan suatu konten, konten tersebut tidak merugikan orang lain. Begitu pula dengan konten-konten yang kita bagikan, baca dengan baik isi konten dan pastikan kebenaran isinya sebelum membagikannya. Jangan sampai kita membagikan hoax atau konten yang berisi penipuan dan penyalahgunaan lainnya. Selain itu pembatasan informasi yang kita terima dari media sosial juga perlu dilakukan. Terlalu sering membaca tentang konten negatif; misanya konten berisi amarah akan mempengaruhi jiwa/ hati kita. Membuat kita kecanduan dengan rasa marah sehingga setiap kali terhubung dengan media sosial, kita akan terus mencari dan membaca konten berisi amarah.

\section{Kesimpulan}

Aplikasi media sosial di dunia sekarang ini menjadi alat yang paling efisien untuk pengusaha bisnis kecil dan biasanya semua UKM keramik menggunakan platform media sosial untuk iklan dan publisitas produk dengan membuat halaman penggemar untuk para pengikut dan dengan hangat menyambut saran juga pendapat yang membantu dalam meningkatkan bisnis. Berdasarkan teori dan undang-undang jelas bahwa jika UKM alat media sosial dengan pendekatan yang tepat dan tujuan yang jelas, mereka dapat dengan mudah mencapai target pelanggannya. Para pengguna UKM, dengan menggunakan pendekatan yang benar di media sosial akan membantu 
membangun hubungan jangka panjang antara pebisnis dan pelanggan. Media sosial memberi kesempatan kepada konsumen dan pengusaha bisnis untuk berkomunikasi secara efektif. Media sosial dapat membantu UKM untuk memperluas bisnis mereka dengan menggunakan berbagai ikatan lemah namun ada beberapa masalah dengan media sosial yang dihadapi oleh bisnis kecil seperti teknologi begitu dinamis dan belum menjadi pedoman yang jelas bagi bisnis tentang bagaimana memanfaatkannya dan mereka meluncurkan kampanye media sosial tanpa tujuan strategis yang jelas. Jadi, menurut pengamatan saya dengan membaca ulasan literatur, aplikasi media sosial memiliki dampak positif pada pengusaha bisnis kecil dan pengusaha sangat termotivasi untuk menggunakan platform ini karena membutuhkan anggaran minimum atau bahkan gratis di sebagian besar situs media sosial untuk mengiklankan produk dan media sosial mereka menciptakan interaksi dan persepsi pelanggan bersifat inklusif dan media partisipatif selain itu media sosial memberikan peluang penanganan umpan balik secara real time. Dampak lainnya untuk pemanfaatan media sosial bisa memberikan peningkatan jangkauan dan eksposur (brand awareness) yang lebih baik, berinteraksi dengan follower (engagement), dan dapat memberikan solusi kepada follower (selling). Namun demikian dan meskipun dampak positif yang dirasa banyak manfaatnya juga tetap harus diperhatikan dampak negatifnya sehingga bisa tetap waspada dan berhati-hati.

\section{Saran}

$\begin{array}{llr} & \text { Pertama lakukan pengenalam } \\ \text { produk dan promosi } & \text { dengan } \\ \text { mengunakan media sosial seperti; }\end{array}$

facebook, Linked-In, jejaring sosial pribadi (yammer, social cast, jive) situs berbagi konten (YouTube, flicker), blog wiki (Wikipedia) (blogger, word press) maupun di blog mikro (twitter). Kedua, buatlah kerjasama dengan berbagai pelaku bisnis lainnya atau lakukan joint business system konsinyasi atau sistem bagi hasil dengan minimarket,dept store ataupun dengan koperasi perusahaan baik yang ada diseluruh Indonesia maupun dengan dunia internasional. Ke tiga melakukan backup pemasaran temporary dengan event atau bazar yang ada disetiap moment acara. Dan tak mungkin penjualan tanpa dilengkapi media promosi seperti dengan membuat brosur atau katalog dan produk,iklan atau reklame di jalan, radio televisi bahkan surat kabar yg dilakukan secara bertahap.

\section{Daftar Pustaka}

Alo Lileweri, MS (2015) Komunikasi Antar Personal, Prenadamedia Group, 9 : 326-336

Blackshaw P, Nazzaro M (2004) Consumer-Generated Media (CGM) 101: Word-of-mouth in the age of the Web fortified consumer.

Boyd DM, Ellison NB (2008) Social Network Sites: Definition, History and Scholarship.

Journal of Computer-Mediated Communication 13: 210-230.

Burt RS (2004) Structural Holes and Good Ideas. American Journal of Sociology 110: 349399.

Cheung CMK, Lee MKO (2010) A theoretical model of intentional social action in online social networks. Decision Support Systems 49: 24-30.

Evan D, Bratton S (2008) Social Media Marketing an Hour a Day: Wiley publishing. 
Fischer E, Reuber AR (2010) Social interaction via new social media: (How) can interactions

on Twitter affect effectual thinking and behavior? Journal of Business Venturing 26: 1-18.

Fulk J, Schmitz J, Steinfield CW (1990) A Social Influence Model of Technology Use. Sage, Newbury Park, CA

Gillin P (2009) Secrets Of Social Media Marketing: How To Use Online Conversations And Customer Communities To Turbo-Charge Your Business. Fresno, CA: Quill Driver Books.

Granovetter MS (1973) The strength of weak ties. American journal of sociology

78: 1360-1380.

AGunther O, Krasnova H, Riehle D, Schondienst V (2009) Modeling Microblogging Adoption

in the Enterprise. 15th Americas Conference on Information Systems

pp: 1-10.

Karkkainen H, Jussila J, Vaisanen J (2010) Social media use and potential in business-to

business companies' innovation. Proceedings of the 14th International Academic MindTrek Conference: Envisioning Future Media Environments, Tampere, Finland

Mangold WG, Faulds DJ (2009) Social media: The new hybrid element of the promotion

mix. Business Horizons 52: 357365.

Meyer P, Dibbern J (2010) An Exploratory Study About Microblogging Acceptance At Work An

Exploratory Study About
Microblogging Acceptance At
Work. AMCIS 2010 Proceedings of
the sixteenth Americas conference
on information systems, Lima, Peru.

Shabbir MS (2015) Innovation and Competitiveness Lead to Industrial Trade. Business and Economics Journal 6: 181.

Shabbir MS (2015) Why Manufacturers are Less Powerful than Retailers in Trade Circles? A Case

Study of Wal-Mart Retailing Business. Business and Economics Journal 6: 177.

Shabbir MS (2014) The Impact Of Human Resource Practices On Employee Perceived Performance In Pharmaceutical Sector Of Pakistan. African Journal of Business Management 8: 626-632.

Tuten LT (2008) Advertising 2.0: Social Media Marketing In A Web 2.0 World. Westport: Praeger Publisher.21. 